\title{
PENGARUH MODEL PEMBELAJARAN BERBASIS MASALAH (PBM) BERBANTUAN MULTIMEDIA TERHADAP KEMAMPUAN BERPIKIR KRITIS PESERTA DIDIK KELAS VII SMP NEGERI 2 MATARAM DITINJAU DARI KEMAMPUAN AKADEMIK
}

\section{THE EFFECT OF PROBLEMS BASED LEARNING (PBL) WITH MULTIMEDIA TOWARDS CRITICAL THINKING SKILLS AT THE FIRST CLASS STUDENTS OF SMP 2 MATARAM IN TERMS OF ACADEMIC ABILITY}

\author{
Susilawati 1), Jamaluddin 2), Imam Bachtiar ${ }^{3)}$ \\ ${ }^{1)}$ Mahasiswa Program Magister Pendidikan IPA Universitas Mataram, Mataram \\ ${ }^{2)}{ }^{3)}$ Dosen PSM PIPA Pascasarjana Universitas Mataram, Mataram \\ Email: Susilawatibio@ymail.com
}

Diterima: 29 Agustus 2017. Disetujui 15 September 2017. Dipublikasikan: 30 September 2017

\begin{abstract}
Abstrak. Pembelajaran berbasis masalah berbantuan multimedia merupakan model pembelajaran dan media pembelajaran yang dirancang secara terintegrasi. Tujuan penelitian adalah untuk mengetahui pengaruh model pembelajaran berbasis masalah (PBM) berbantuan multimedia terhadap kemampuan berpikir kritis peserta didik dan kemampuan akademik. Jenis penelitian ini adalah eksperimen semu (quasy experiment) dengan desain penelitain non Equivalent pretest-posttest control group design. Populasi dalam penelitian ini adalah peserta didik kelas VII SMP Negeri 2 Mataram Tahun Pelajaran 2017/2018, dan penentuan sampel dilakukan dengan Haphazard Sampling, sampel yang diambil dalam penelitian ini adalah peserta didik kelas VII sebanyak 4 (empat) kelas. Instrumen yang digunakan untuk mengukur kemampuan berpikir kritis adalah lembar observasi keterlaksanaan RPP dan tes uraian. Data dianalisis menggunakan uji Anova dua jalur (Two Way Anava). Hasil penelitian menunjukkan bahwa: (1) Model pembelajaran berbasis masalah berbantuan multimedia secara signifikan berpengaruh terhadap kemampuan berpikir kritis peserta didik; (2) Kemampuan akademik berpengaruh terhadap kemampuan berpikir kritis peserta didik; (3) Tidak ada interaksi antara model pembelajaran berbasis masalah berbantuan multimedia dengan kemampuan akademik terhadap kemampuan berpikir kritis.
\end{abstract}

Kata Kunci: Model Pembelajaran Berbasis Masalah (PBM), Multimedia, Kemampuan Berpikir Kritis

Abstract. Problem-based learning is an integrated learning model and instructional media. The purpose of this research is to know the effect of problem based learning model (PBM) with multimedia and academic ability towards students' critical thinking ability. This research is a quasi experiment with non-equivalent pretest-posttest control group design. The population of this study was students at the first grade of SMPN 2 Mataram in academic year 2017/2018, and sample determination was done with Haphazard Sampling . The samples of this study were 4 (four) classes of students at the first grade of SMPN 2 Mataram. The instruments used to measure students' critical thinking ability are observation sheets of lesson plan implementation and description test. The data were analyzed using two way Anova test (Two Way Anova). The results showed that: (1) Problem-based learning model significantly influences the students' critical thinking ability; (2) The academic ability does affect the students' critical thinking ability; (3) There is no interaction between problem-based learning model and academic ability in critical thinking ability.

Keywords: Problem Based Learning Model (PBM), Multimedia, Critical Thinking skill

\section{PENDAHULUAN}

Tantangan abad 21 menuntut pemikiranpemikiran inovatif yang didasari dari berpikir ilmiah dan penemuan ilmiah. Masyarakat membutuhkan generasi yang dapat menciptakan teknologi baru yang bisa menjadi dasar dalam menghadapi tantangan ekonomi, sosial, dan lingkungan. Pendidikan hendaknya menghasilkan generasi yang memiliki dasar pemikiran dan penemuan ilmiah yang inovatif untuk menopang daya saing Indonesia di kancah dunia, tanpa 
melupakan aspek dampak sosial yang ditimbulkan. Oleh karenanya, agar mampu bertahan berkompetisi dalam menghadapi peluang dan tantangan global dimasa depan, setiap individu dituntut memiliki pemikiran yang memadai mencakup pengetahuan tentang sains, keterampilan proses sains dan sikap ilmiah.

Peningkatan kualitas pendidikan sains dapat dilakukan melalui berpikir sains. Dimana berpikir sains dapat dikembangkan melalui kemampuan berpikir tingkat tinggi (expert thinking). Kemampuan berpikir tingkat tinggi ini dapat dijadikan pondasi untuk membentuk karakter bangsa.

Gejala umum yang terjadi pada peserta didik adalah "malas berpikir" mereka cenderung menjawab pertanyaan dengan cara mengutip buku atau bahan pustaka lain tanpa mengungkapkan pendapat atau analisisnya terhadap pendapat tersebut. Bila keadaan ini berlangsung terus menerus maka peserta didik akan mengalami kesulitan mengaplikasikan pengetahuan yang diperoleh di kelas dan kehidupan nyata.

Strategi pembelajaran yang diterapkan belum mengakomodasi seluruh karakter kemampuan akademik peserta didik, sehingga jarak antara peserta didik berkemampuan akademik tinggi dan rendah masih tetap jauh. Menurut Nasution (2010) dalam Gayatri [1] secara alami dalam satu kelas kemampuan akademik peserta didik bervariasi, yakni ada yang tinggi, sedang dan rendah yang dapat disebabkan karena faktor bawaan atau lingkungan hidupnya misalnya tempat tinggal, latar belakang peserta didik, dan tingkat sosial ekonomi.

Rofi'udin [2] lebih lanjut menyatakan bahwa terjadi keluhan tentang rendahnya kemampuan berpikir kritis-kreatif yang dimiliki oleh lulusan pendidikan dasar sampai perguruan tinggi karena pendidikan berpikir belum ditangani dengan baik. Oleh karena itu, penanganan kecakapan berpikir kritis-kreatif sangat penting diintegrasikan dalam setiap mata pelajaran.

Ketidak berhasilan guru dalam menanamkan keterampilan-keterampilan di atas juga terlihat dari rendahnya nilai rata-rata ulangan harian peserta didik di SMP Negeri 2 Mataram khususnya di kelas VII. Melalui pembelajaran IPA di sekolah, guru belum menumbuh kembangkan kemampuan berpikir kritis peserta didik, guru biasanya menggunakan model pembelajaran langsung di mana peserta didik memperoleh materi semata-mata dari guru, sedangkan peserta didik kurang aktif terlibat dalam pembelajaran. Hal ini menyebabkan peserta didik kurang mampu membangun pengetahuan sendiri sehingga keterampilan berpikirnya kurang terlatih.

Upaya untuk menghadapi permasalahan di atas, maka dibutuhkan suatu inovasi model pembelajaran yang mampu membuat peserta didik dapat mengaplikasikan ilmunya dalam menghadapi permasalahan di kehidupan seharihari. Salah satu model pembelajaran yang dapat menarik peserta didik untuk ikut aktif dalam proses pembelajaran adalah pembelajaran berbasis masalah (PBM). Menurut Noordin (2011) dalam Safitri [3] model pembelajaran berbasis masalah merupakan strategi pengajaran yang inovatif dimana guru mendorong siswa untuk mengembangkan kemampuan dalam pemecahan masalah, kreativitas dan keterampilan berpikir kritis.

Selain penggunaan model pembelajaran yang bervariasi, media pembelajaran merupakan sesuatu yang tidak kalah penting dalam kegiatan pembelajaran. Salah satu media pembelajaran yang dapat memfasilitasi peserta didik dalam pemenuhan gaya belajar baik dari segi visual, audio, maupun kinestetik untuk mencapai tujuan pembelajaran adalah multimedia berbasis komputer. Menurut Giavrimis [4] penggunaan multimedia dalam peningkatan kemampuan berpikir kritis peserta didik dapat dioptimalkan fungsinya jika dikombinasikan dengan model pembelajaran yang tepat. Penelitian terkait keefektifan model pembelajaran ini sebelumnya sudah pernah dilakukan $[5,6]$ Oleh karena itu, dengan media pembelajaran dan model pembelajaran yang bervariasi diharapkan peserta didik tidak mengalami kejenuhan sehingga merasa senang dalam mengikuti pelajaran.

Berdasarkan pemikiran dan permasalahan yang telah diuraikan di atas, maka penulis tertarik untuk melakukan penelitian dengan judul "Pengaruh Model Pembelajaran Berbasis Masalah (PBM) Berbantuan Multimedia Terhadap Kemampuan Berpikir Kritis Peserta Didik Kelas VII SMPN 2 Mataram Ditinjau Dari Kemampuan Akademik".

\section{METODE PENELITIAN}

Penelitian ini merupakan penelitian quasi eksperimen (quasi experimental design), desain yang digunakan dalam penelitian ini adalah non Equivalent pretest-posttest control group design. Sedangkan rancangan penelitian yang digunakan 
adalah rancangan faktorial $2 \times 2$. Populasi yang digunakan dalam penelitian ini adalah peserta didik kelas VII SMP Negeri 2 Mataram yang terdiri dari sepuluh kelas. Sedangkan sampel dalam penelitian ini diambil 4 kelas sebagai kelas penelitian.

Teknik pengambilan sampel dilakukan dengan cara Haphazard Sampling, yaitu melakukan observasi dan mewancarai secara langsung guru yang mengajar di kelas VII, untuk memperoleh informasi terkait peserta didik yang dijadikan sampel penelitian. Sampel dalam penelitian ini diambil 4 (empat) kelas yang dianggap dapat merepresentasikan populasi kelas VII di SMPN 2 Mataram.

Instrumen penelitian yang digunakan yakni lembar observasi keterlaksanaan RPP, berupa check list keterlaksanaan sintaks pembelajaran yang diisi oleh observer, tes hasil belajar kemampuan berpikir kritis dalam bentuk soal uraian yang berjumlah 5 (lima) item. Analisis data diawali dengan uji normalitas dan uji homogenitas dengan bantuan SPSS versi 16, kemudian dilanjutkan dengan uji hipotesis menggunakan uji Anova dua faktor.

Untuk mengetahui peningkatan nilai rata-rata peserta didik pada saat pre-test dan post-test, dilakukan analisis $\mathrm{N}$-Gain terhadap kemampuan berpikir kritis peserta didik dengan menggunakan persamaan:

$$
N-\text { Gain }=\frac{\text { Skor } \text { Post-Skor Pre }}{\text { Skor Max-Skor Pre }} \times 100 \%
$$

Hasil perhitungan $N$-gain kemudian diinterpretasikan menjadi 3 (tiga) kriteria.

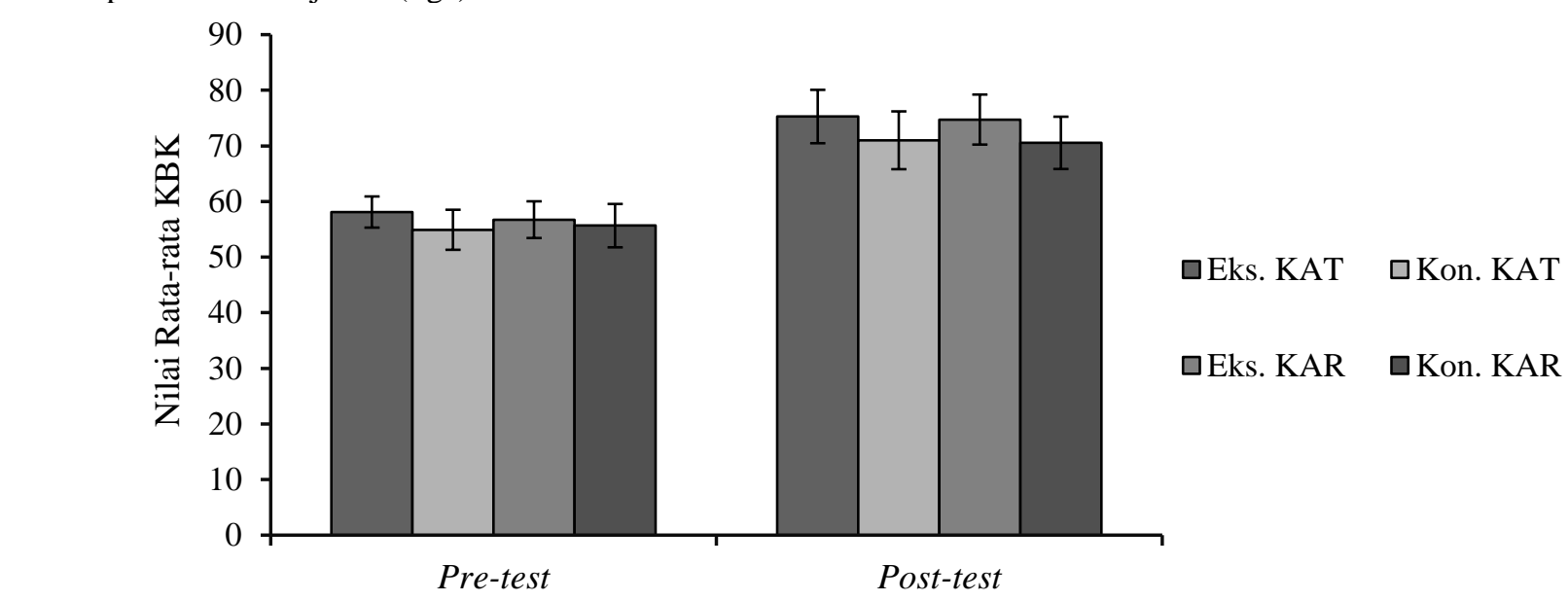

Gambar 1. Perbandingan Nilai Rata-rata Pre-test, Post-test KBK. Batang Galat Menunjukkan 1 SD. Eks.=

Eksperimen; Kon= Kontrol; KAT= Kelompok Akademik Tinggi; KAT= Kelompok Akademik Rendah
Tabel 1. Kriteria N-Gain

\begin{tabular}{ll}
\hline \multicolumn{1}{c}{ Presentase } & \multicolumn{1}{c}{ Kategori } \\
\hline$N$-gain $>0,70$ & Tinggi \\
$0,70>N$-gain $\geq 0,30$ & Sedang \\
$N$-gain $<0,30$ & Rendah \\
\hline & Sumber: Hake, 1999
\end{tabular}

\section{HASIL DAN PEMBAHASAN}

Nilai rata-rata $( \pm \mathrm{SD})$ pre-test di masingmasing kelompok akademik (KAT dan KAR) baik di kelas eksperimen maupun kontrol tidak menunjukkan perbedaan yang besar (Gambar 1). Nilai rata-rata pre-test KBK peserta didik di KAT kelas eksperimen dan kontrol mempunyai nilai rata-rata yang hampir sama, secara berurutan yakni 58,10 $( \pm 2,8)$ dan $54,91( \pm 3,6)$, sedangkan nilai rata-rata pre-test $\mathrm{KBK}$ peserta didik pada KAR baik di kelas eksperimen maupun kontrol secara berurutan $56,73( \pm 3,3)$ dan $55,65( \pm 3,9)$.

Nilai rata-rata $( \pm \mathrm{SD})$ post-test KBK peserta didik di kelas eksperimen dan kontrol pada KAT dan KAR tidak menunjukkan adanya perbedaan yang begitu besar, sebab kedua kelompok akademik (KAT dan KAR) di kelas eksperimen dan kontrol mempunyai nilai rata-rata yang hampir sama. Nilai rata-rata post-test di kelas eksperimen pada KAT dan KAR secara berurutan $75,27( \pm 4,8)$ dan $74,73(4,5)$, sedangkan nilai ratarata post-test di kelas kontrol pada KAT dan KAR secara berurutan $71,00( \pm 5,2)$ dan 70,54 $( \pm 4,7)$. 


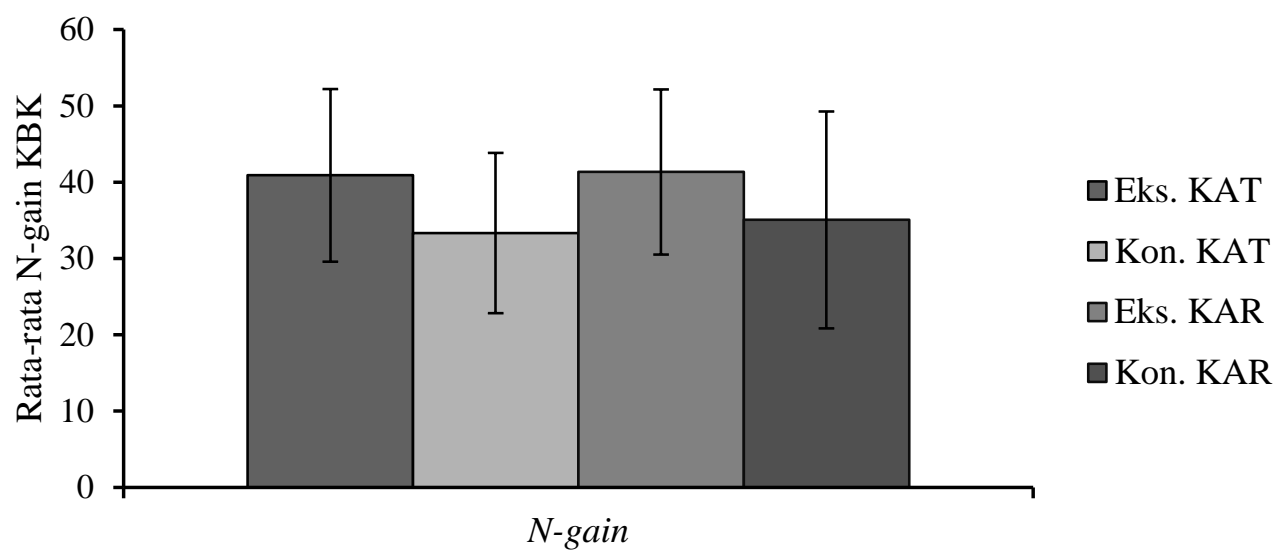

Gambar 2. Perbandingan nilai rata-rata $N$-gain KBK. Batang Galat Menunjukkan 1 SD. Eks.= Eksperimen; Kon.= Kontrol; KBK= Kemampuan Berpikir Kritis; KAT= Kemampuan Akademik Tinggi; KAR=

Kemampuan Akademik Rendah

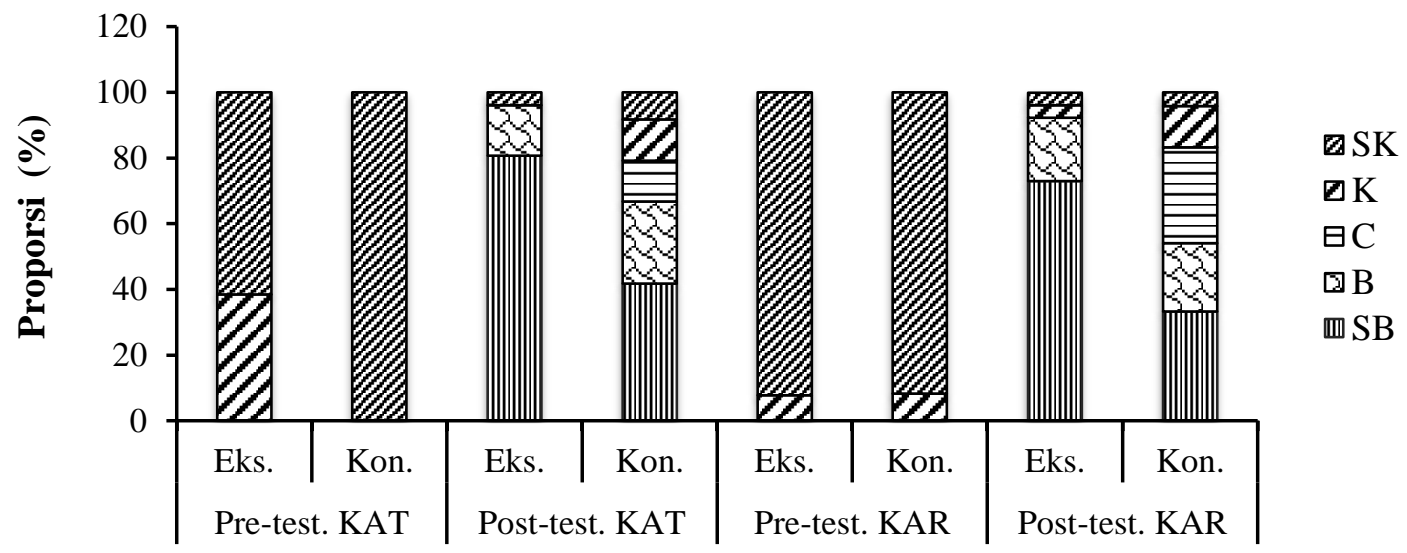

Gambar 3. Perbandingan Kriteria Hasil Belajar Kemampuan Berpikir Kritis Peserta Didik. SB= Sangat Baik; $\mathrm{B}=$ Baik; $\mathrm{C}=$ Cukup; K= Kurang; SK= Sangat Kurang

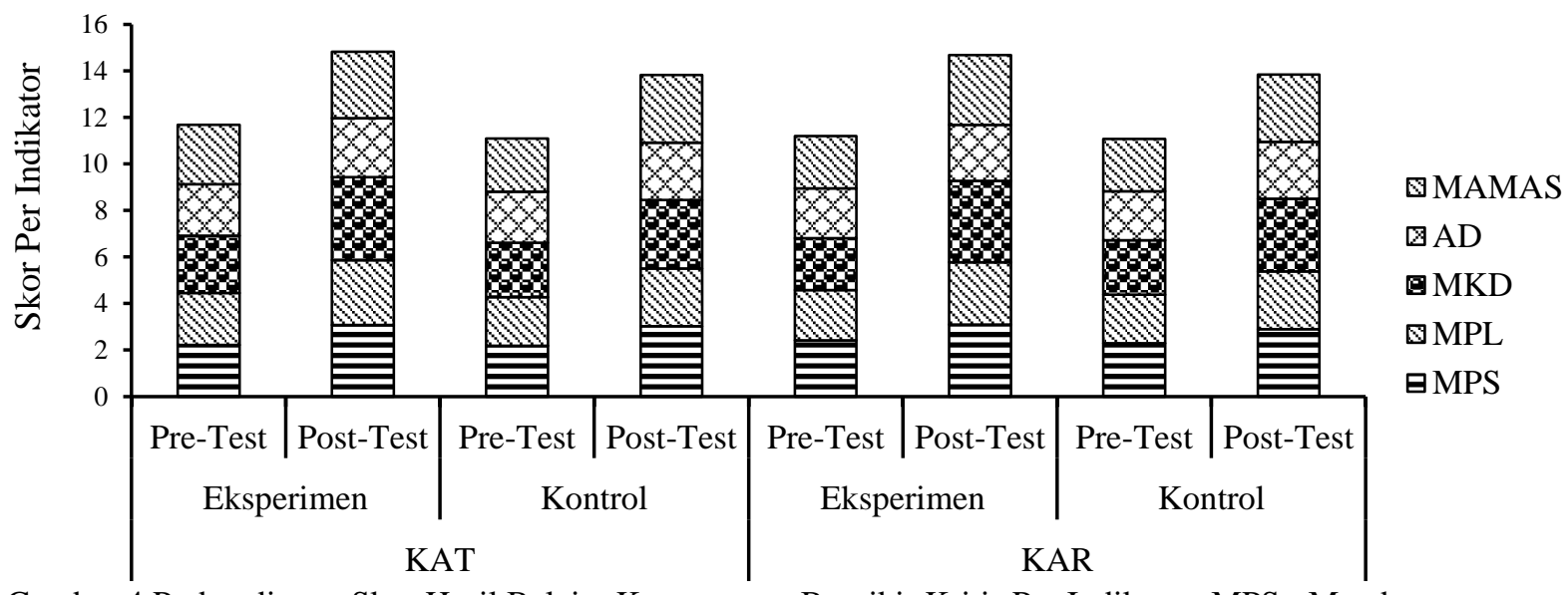

Gambar 4 Perbandingan Skor Hasil Belajar Kemampuan Berpikir Kritis Per Indikator. MPS= Membuat Penjelasan Sederhana; MPL= Membuat Penjelasan Lebih Lanjut; MKD= Membangun Keterampilan Dasar; $\mathrm{AD}=$ Analisis Data; MAMAS= Mengidentifikasi Asumsi dan Memutuskan Alternatif Untuk Solusi 
Perbandingan nilai rata-rata $N$-gain $\mathrm{KBK}$ peserta didik menunjukkan bahwa $\mathrm{N}$-gain di KAT maupun KAR di kelas eksperimen dan kontrol hampir sama, artinya peningkatan hasil belajar KBK di kedua kelompok akademik (KAT dan KAR) tidak begitu besar (Gambar 2). Tetapi, ratarata $N$-gain lebih tinggi di KAR daripada KAT baik di kelas eksperimen maupun kontrol. Di kelas eksperimen pada KAT dan KAR, mempunyai $N$-gain dengan rata-rata secara berurutan 40,89 $( \pm 11,31)$ dan 41,33 $( \pm 10,82)$, sedangkan di kelas kontrol mempunyai $\mathrm{N}$-gain dengan rata-rata 33,33 $( \pm 10,50)$ di KAT dan 35,03 $( \pm 14,21)$ di KAR.

Sebelum diberikan perlakuan baik di kelas eksperimen maupun kontrol KAT, rata-rata KBK peserta didik di bawah kategori sangat baik, akan tetapi setelah diberikan perlakuan KBK peserta didik meningkat, di kelas eksperimen 80,7\% KBK termasuk dalam kategori sangat baik, sedangkan di kelas kontrol 41,7\% KBK termasuk dalam kategori sangat baik.

Baik di kelas eksperimen maupun kontrol KAR, sebelum diberikan perlakuan rata-rata KBK peserta didik hampir sama yakni di bawah kategori sangat baik, akan tetapi setelah diberikan perlakuan kemampuan berpikir kritis meningkat, 73\% KBK termasuk dalam kategori sangat baik di kelas eksperimen, dan 33,3\% KBK termasuk dalam kategori sangat baik di kelas kontrol (Gambar 3).

Indikator berpikir kritis yang diukur dalam penelitian ini adalah 5 (lima) indikator. Dari kelima indikator berpikir kritis yang diukur, ada 4 (empat) indikator yang menunjukkan variasi besar, yakni indikator pertama, kedua, ketiga dan indikator kelima, baik di kelas ekperimen maupun kontrol pada KAT dan KAR.

Pada indikator keempat analisis data, nilai rata-rata menunjukkan perbedaan yang tidak jauh berbeda baik di kelas eksperimen maupun kontrol pada KAT dan KAR. Hal ini disebabkan karena peserta didik masih kurang bisa didalam menginterpretasikan sebuah data dalam bentuk tabel ataupun grafik (Gambar 4).

\section{Pengaruh Model Pembelajaran Berbasis Masalah Berbantuan Multimedia Terhadap Kemampuan Berpikir Kritis Peserta Didik}

Hasil uji hipotesis terhadap kemampuan berpikir kritis peserta didik menunjukkan bahwa, model PBM berbantuan multimedia berpengaruh terhadap kemampuan berpikir kritis peserta didik
$(\mathrm{F}=14,948 ; d f=1,99 ; \mathrm{p}<0,05)$. Hasil penelitian ini sejalan dengan penelitian yang dilakukan sebelumnya $[8,9,10]$.

Terjadinya peningkatan kemampuan berpikir kritis dalam penelitian ini karena pada dasarnya PBM merupakan model pembelajaran berbasis konstruktivis, sehingga membantu peserta didik dalam pematangan konsep yang dimiliki. Temuan dalam penelitian ini dipertegas oleh hasil penelitian Selahatin [11].

\section{Pengaruh Kemampuan Akademik Terhadap Kemampuan Berpikir Kritis Peserta Didik}

Kemampuan akademik berpengaruh terhadap kemampuan berpikir kritis peserta didik $(\mathrm{F}=$ $10,445 ; d f=1,99 ; \mathrm{p}>0,05)$. Hasil penelitian ini sejalan dengan penelitian yang dilakukan Jamaluddin (2009) dalam Utami [12] yang menyatakan kemampuan akademik berpengaruh terhadap pemahaman konsep IPA peserta didik.

Dalam penelitian ini, rata-rata $N$-gain pada kelas eksperimen maupun kontrol lebih tinggi pada peserta didik KAR daripada KAT. Hasil penelitian ini tidak mendukung teori yang disampaikan oleh Nasution (1988) dalam Muhfaroyin [13] yang mengatakan bahwa peserta didik dengan tingkat kemampuan akademik berbeda diberi pembelajaran yang sama, maka hasil belajarnya akan berbeda.

Kerja kelompok dilaksanakan dengan menekankan tahap PBM, kerjasama yang baik dalam kelompok ditunjukkan dengan pembimbingan dari peserta didik yang memiliki kemampuan akademik tinggi kepada peserta yang memiliki kemampuan akademik rendah. Pembelajaran ini memiliki beberapa perspektif yang dapat dikembangkan, yaitu perspektif motivasi, sosial, kognitif, elaborasi kognitif, dan psikologis.

\section{Pengaruh Interaksi Model Pembelajaran Berbasis Masalah Berbantuan Multimedia Dengan Kemampuan Akademik Terhadap Kemampuan Berpikir Kritis Peserta Didik}

Interaksi model pembelajaran berbasis masalah (PBM) berbantuan multimedia dengan kemampuan akademik tidak berpengaruh terhadap kemampuan berpikir kritis peserta didik $(\mathrm{F}=0,336 ; d f=1 ; 99 ; \quad \mathrm{p}>0,05)$. Hasil ini memberikan makna bahwa model pembelajaran berbasis masalah (PBM) berbantuan multimedia dapat diterapkan baik pada peserta didik 
berkemampuan akademik tinggi maupun peserta didik berkemampuan akademik rendah.

Adanya persamaan kemampuan kemampuan berpikir kritis peserta didik berdasarkan tingkat kemampuan akademik tiada lain juga dipengaruhi oleh faktor lingkungan dan pengalaman belajar peserta didik.

Hal ini sesuai dengan hasil penelitian Behar-Horeinstein [14] yang menyatakan bahwa perbaikan dalam berpikir kritis peserta didik dipengaruhi juga karena adanya faktor-faktor dari luar seperti lingkungan belajar dan persiapan serta panjangnya pengalaman guru dalam mengajar.

Model pembelajaran berbasis masalah (PBM) berbantuan multimedia ini dapat diterapkan pada semua mata pelajaran di sekolah. Akan tetapi, untuk menerapkan model pembelajaran ini guru perlu mengkaji materi yang akan disampaikan untuk disesuaikan dengan aktivitas dalam model PBM itu sendiri, sebab model PBM ini bercirikan menggunakan masalah dalam kehidupan nyata sebagai sesuatu yang harus dipelajari peserta didik untuk melatih dan meningkatkan kemampuan berpikir dan pemecahan masalah, serta mendapatkan pengetahuan konsep penting.

Jadi, berdasarkan permasalahan yang diberikan peserta didik akan terpacu untuk mendiskusikan berbagai alternatif pemecahannya bersama dengan kelompoknya. Selain itu, didalam tampilan media guru juga dapat menampilkan atau menyajikan pertanyaan yang mengarahkan peserta didik untuk mampu menganlisis keterkaitan materi yang dipelajari dengan berbagai aplikasinya dalam kehidupan nyata.

Dengan demikian, pembelajaran berbasis (PBM) berbantuan multimedia dapat dijadikan sebagai referensi bagi guru dalam melaksanakan proses pembelajaran di kelas.

\section{KESIMPULAN}

Berdasarkan hasil penelitian dan pembahasan dapat disimpulkan bahwa, ada pengaruh model pembelajaran berbasis masalah berbantuan multimedia dan pengaruh kemampuan akademik terhadap kemampuan berpikir kritis peserta didik, sedangkan pengaruh interaksi kedua faktor tidak terbukti

\section{DAFTAR PUSTAKA}

[1] Gayatri, I. G. A. S., Jekti, D. S. D., \& Jufri, A. W. (2013). Efektifitas Pembelajaran Berbasis Masalah (PBM) Dan Strategi Kooperatif Terhadap Kemampuan Menyelesaikan Masalah Dan Hasil
Belajar Kognitif Biologi Ditinjau Dari Kemampuan Akademik Awal Siswa Kelas X SMA Negeri 3 Mataram. Jurnal Pijar Mipa, 8(2): 41-46

[2] Rofi'uddin, A. 2000. Model Pendidikan Berpikir Kritis-Kreatif Untuk Siswa Sekolah Dasar. Majalah Bahasa dan Seni 1(28): 72-94

[3] Safitri, E. H., Siahaan, J., \& Al Idrus, S. W. (2015). Studi Komparasi Hasil Belajar Kimia Pada Materi Koloid Menggunakan Model Pembelajaran Berbasis Proyek Dan Model Pembelajaran Berbasis Masalah Siswa Kelas XI IPA MAN 2 Mataram Tahun Ajaran 2013/2014. Jurnal Pijar Mipa, 10(1): 52-56

[4] Giavrimis, P., Papanis, E. \& Papanis, E.M. 2011. Information And Communication Technologies And Development Of Learners' Critical Thinking: Primary School Teachers'Attitudes. International Education Studies 4 (3): 150-160.

[5] Ariyati, E. 2015. Pembelajaran Berbasis Masalah Untuk Mengembangkan Kemampuan Berpikir Kritis Mahasiswa. Prosiding Seminar Nasional Pendidikan Biologi 2015, yang diselenggarakan oleh Prodi Pendidikan Biologi FKIP Universitas Muhammadiyah Malang, tema: "Peran Biologi dan Pendidikan Biologi dalam Menyiapkan Generasi Unggul dan Berdaya Saing Global. Universitas Tanjungpura

[6] Al-idrus, S. Q. M. J., Hikmawati, H., \& Wahyudi, W. (2015). Pengaruh Model Pembelajaran Berbasis Masalah Berbantuan Video Kartun Terhadap Hasil Belajar Fisika Siswa Kelas XI SMAN1 Sikur Tahun Ajaran 2014/2015. Jurnal Pijar Mipa 10(1): 22-25

[7] Hake, R. 1999. Analyzing Change / Gain Score. Indiana: Indiana University.

[8] Sari, D.S., dan Sugiyarto, K.H. 2015. Pengembangan multimedia berbasis masalah untuk meningkatkan motivasi belajar dan Kemampuan berpikir kritis 
siswa. Jurnal Inovasi Pendidikan IPA 1(2): 153-166

[9] Ramadhan, M., I., Aeni, N., A., Sujana, A. 2016. Penerapan Model PBL Berbantuan Multimedia Untuk Meningkatkan Hasil Belajar Peserta Didik Pada Materi Daur Ulang Air Dan Peristiwa Alam. Jurnal Pena Ilmiah 1(1)

[10] Sudiatmika, M., A., Subagia, I., W., Muderawan, I, W. 2016. Pengaruh Penggunaan Multimedia Pada Model Problem Based Learning (PBL) Terhadap Hasil Belajar Kimia Siswa. Prosiding Seminar Nasional.

[11] Selahatin, G.,K., \& Inan. 2006. The Effect Of The Computer Assisted Taching And 7e Model Of The Contructivist Learning Methods On The Achievements And Attitudes Of High School Students. The Tukish Online Journal Of Educational Technology

[12]Utami, S.D. 2014. Pengaruh Penerapan Model Pembelajaran Kooperatif Berbasis Pemberdayaan Berpikir Terhadap Kemampuan Berpikir Kritis dan Hasil Belajar IPA DiTinjau Dari Kemampuan Akademik Siswa. Tesis. Universitas Mataram.

[13] Muhfaroyin. 2009. Pengaruh Strategi Think Pair Share (TPS) dan Kemampuan Akademik Terhadap Kemampuan Berpikir Kritis Siswa Di Kota Metro 16(2)

[14] Behar-Horenstein, L. S., \& Niu, L. (2011). Teaching Critical Thinking Skills In Higher Education: A Review Of The Literature. Journal of College Teaching and Learning, 8(2): 25 